\title{
Modification and Optimization of a Baking Oven for Small Scale Bread Production
}

\author{
Babajide S. Kosemani*, Adeyinka T. Ilori, Ayoade 0. Atere \\ Agricultural and Bio-Environmental Engineering, Federal College of Agriculture, Ibadan, Nigeria \\ Email: ^indizjiddy@yahoo.com, kosemani.bs@fcaib.edu.ng
}

How to cite this paper: Kosemani, B.S., Ilori, A.T. and Atere, A.O. (2021) Modification and Optimization of a Baking Oven for Small Scale Bread Production. Agricultural Sciences, 12, 630-644. https://doi.org/10.4236/as.2021.126041

Received: April 30, 2021

Accepted: June 21, 2021

Published: June 24, 2021

Copyright (C) 2021 by author(s) and Scientific Research Publishing Inc. This work is licensed under the Creative Commons Attribution International License (CC BY 4.0).

http://creativecommons.org/licenses/by/4.0/

(c) (i) Open Access

\begin{abstract}
An existing small-scale single-powered baking oven was modified and optimize into a dual-powered oven. The oven was redesigned to accommodate the initially designed firewood heat source and the newly introduced gas heat source. Four heat exchangers (thermal pipes) were introduced to the baking chamber for effective heat and mass transfer during baking of bread dough. The thermal pipes were made of $2 \mathrm{~mm}$ thick hollow galvanized steel pipe of $23 \mathrm{~mm}$ diameter and $660 \mathrm{~mm}$ length. The performance of the oven was evaluated using the standard performance index, which includes baking capacity, baking efficiency and weight loss of the baked bread. The baked bread's physical properties were determined and analyzed using Duncan multiple range ANOVA test at significant level of $p<0.05$. These properties were optimized to determine the generate regression models using $3 \mathrm{D}$ model plot. The baking capacity, baking efficiency, weight loss and optimum baking temperature were: $101.9 \mathrm{~kg} / \mathrm{h}, 46.44 \%$ (wood-fired); 70.34\% (gas-fired), $13.5 \mathrm{~g}$ (wood-fired); and $25.5 \mathrm{~g}$ (gas-fired), $150^{\circ} \mathrm{C}$, respectively. The physical properties of baked bread, wood-fired were found to correspond with that of gas-fired oven. The modified oven can be used for the baking of dough at domestic, small and medium scale bakery.
\end{abstract}

\section{Keywords}

Oven, Modification, Dual Powered, Optimization, Baked Bread

\section{Introduction}

Baking is the most common and oldest form of food processing that uses sustained dry heat through convection instead of thermal radiation normally in the oven, but also in ashes or hot stones [1]. It is a dynamic method of simultaneous heat and mass transfer widely used in food industries. A baking oven is the most 
widely used appliance in food service industry. An oven can be simply described as a fully enclosed thermally insulated chamber use for the heating, baking or drying of a substance [2]. In baking oven, the hot air flows over the material either by natural convection or forced by a fan, the convection heat transfer from air, the radiation heat transfer from the oven heating surfaces, and the conduction heat transfer across contact area between product and metal surface [3]. [4] reported that the moisture in the food material simultaneously diffuses toward the surfaces, then, it transfers from the surface by convection, and the product losses moisture with continuous movement of the oven ambient air. In Nigeria, increasing population, rapid urbanization, and changing food habits have resulted in preference for ready-to-eat convenient foods such as bread, biscuits and other baked products, despite the increase in their prices [5] [6]. Unfortunately, the large-scale bakers utilize the imported ovens, which are unaffordable to small-scale or household bakers [7]. Presently, irregular supply of electricity in Nigeria has rendered electric baking oven unproductive across all levels of operations. Therefore, there is a need for the development of an indigenous gas-fired baking oven, with the enormous availability of liquefied gas. It was reported that gas-fired baking oven enhances flavor and uniform distribution of heat transfer better than any other type of oven [8] [9]. [7] Also reported that the gas-fired oven is cheaper to run than diesel-fired oven, more so that it produced less greenhouse gas which resulted to global warming effect. According to [10], conventional ovens which are usually powered by natural gas or electricity can be very expensive. This in turn discourages baking for domestic purposes because it becomes more economical to buy already baked foods such as bread. In recent days, the electric oven users are facing a problem due to the erratic power cuts in middle of the operations, these causes the loss of the quality of the end product and the loss of the capital and the electric oven consumes more energy [11]. The use of gas as the energy source for baking oven is commercially necessary for most of the regions because the electricity by comparison is prohibitively expensive [12]. Study of baking oven is important because it could lead to a more efficient process of baking favorable energy efficiency and better product quality [11]. The baking process usually requires significant energy consumption as relatively high temperature is applied in order to remove moisture in baked products and create desired texture. Hence, the aim of this work is to modify and evaluate an existing baking oven for small-scale entrepreneurs at affordable cost using local content.

\section{Materials and Methods}

\section{Description of the oven}

The baking oven consists of four units, which includes the heat source or combustion units, baking unit, insulating unit and monitoring unit (Plate 1). The heat source or combustion unit includes combustion chamber, chimney, grate fuel shelf and rocket pipe. A combustion chamber is an internal part of the 


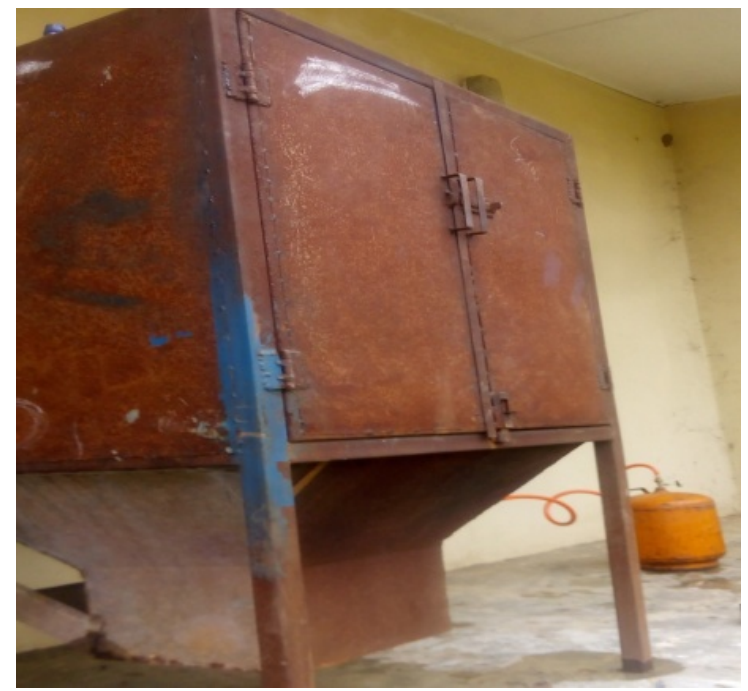

Plate 1. The modified baking oven.

baking oven where fuel/air mix is burned. It was made from $2 \mathrm{~mm}$ sheet metal. The length, breadth and width were 635, 534 and $381 \mathrm{~mm}$, respectively. The chimney is a structure that provides ventilation for hot fuel gases or smoke from combustion chamber to the outside atmosphere. The chimney was $65 \mathrm{~mm}$ in diameter, $3 \mathrm{~mm}$ thick and $70 \mathrm{~mm}$ high.

The chimney was convert with a cap to ensure that moisture from the rain and dust does not have access into the baking chamber through the opening. It was made from $2 \mathrm{~mm}$ sheet metal. The length, breadth and height of the cap were $178 \mathrm{~mm}, 254 \mathrm{~mm}$ and $176 \mathrm{~mm}$, respectively. A fire place is a structure made of metal designed to contain a fire. This is a frame of galvanized metal part where the burning ashes were stored in the oven. The fuel shelf was attached in between a folding plate like rod of 2 quarter and dimension of height $12 \mathrm{~mm}$ and $24 \mathrm{~mm}$ width respectively. A rocket pipe is a metal pipe structure attached with the chimney to aid ventilation for smoke passage from the oven. Baking chamber allows automatic thermal processing or treatment of all types of products at a preset temperature. The chamber is suitable for thermal processing of ham and similar products in leak-proof casings of moulds. Its component parts include baking tray, that are shallow platform design for carrying dough and pastry. It was made of angle bar and iron net which were cut into diameter of $65 \mathrm{~mm} \times 74$ $\mathrm{mm}$ with thickness of $3 \mathrm{~mm}$ respectively. The insulating unit reduces heat transfer (the transfer of thermal energy between objects of differing temperature) between objects in thermal contact or in range of radioactive influence. The main component includes fiber glass, a common type of fiber reinforced plastic using glass fiber. The fibers may be randomly arranged, flattened into a sheet (called a chopped strand mat), or woven into a fabric. The monitoring unit include temperature gauge, a device of a control unit which if fixed to the baking chamber is used to determine the rate of hotness or coldness of baking dough and pastry in an oven. 


\section{Modification}

The materials used for the modification were sourced locally. A preliminary test was carried out on the baking oven, the average thermal efficiency of the machine for both cold and hot start was $26.98 \%$ and $32.36 \%$. The average oven temperature was $124^{\circ} \mathrm{C}$ and average time taken for baking was $44 \mathrm{~min}$. sequel to this test, it was found that the baking unit and combustion unit need to be modified so as to improve the efficiency. This will in turn increase the baking efficiency, reduce the fuel consumption by improving the thermal conductivity and make the baking oven have dual heat source. The baking chamber is where automatic thermal processing by cooking and baking is done. Four heat exchangers (thermal pipes) were introduced to the portable bread baking oven in the baking unit for effective heat and mass transfer during baking of bread dough. They are made of $2 \mathrm{~mm}$ galvanized steel pipe of $23 \mathrm{~mm}$ diameter and $660 \mathrm{~mm}$ length. Transformer oil was then used as the thermal oil. Combustion chamber is the part of an internal combustion baking oven in which the fuel/air mix is burned. A gas burner of nozzle size 0.95 was fitted into the combustion chamber as the source of heat. The outlet part was closed to retain gas pressure for effective atomization. A gas regulator of 0 - 12 bar pressure value was installed to built-up gas pressure and to regulate the flow rate consistently on gas delivery line. It was located in between the gas cylinder regulator and the main gate valve. The principle of a rocket stove was adopted in the construction of baking oven. A rocket stove is an efficient and hot burning portable stove that uses wood fuel and gas fuel. Fuel was burnt in a simple combustion chimney, which ensures almost complete combustion prior to the flames reaching the cooking surface.

\section{Experimentation}

The bread dough was prepared by mixing $12.0 \mathrm{~kg}$ of flour, $18 \mathrm{~g}$ of salt, $300 \mathrm{~g}$ of butter, $18 \mathrm{~g}$ of yeast, 6.0 liters of water, 10 cups of sugar and 12 pieces of egg with a 10-minute planetary dough mixer. The dough was then divided into the required measures and kneaded into a ball shape. The kneaded dough was divided and weighed at 100, 150,200, $250 \mathrm{~g}$ as one set. Four sets were made in triplets for firewood and gas-fired, then molded and placed inside clean and oiled baking pans of four different sizes to produce a moist surface. A set of four sizes of molded dough was placed inside the proofer $45^{\circ} \mathrm{C}$ for 1 hour. During the test process, carbon dioxide is produced by fermentation of the sugar content of the yeast. The result was that the dough rose to almost a doubling height. After the proffering process, they were transferred and properly arranged on the baking tray, then loaded inside the oven and baked at $140^{\circ} \mathrm{C}$ for 20 minutes. These procedures were observed for other two sets of four molded dough at $145^{\circ} \mathrm{C}$ and $150^{\circ} \mathrm{C}$ baking temperature consecutively. The physical dimensions at an interval of 5 mins of loss in the weight, vertical height, length and breadth were measured at a varying baking temperature (Plate 2).

The modified firewood and gas-fired baking oven was evaluated at three levels of temperatures: $140^{\circ} \mathrm{C}, 145^{\circ} \mathrm{C}$, and $150^{\circ} \mathrm{C}$ uninterruptedly during dough baking to establish the optimum baking temperature at a constant period of $20 \mathrm{~min}$. 


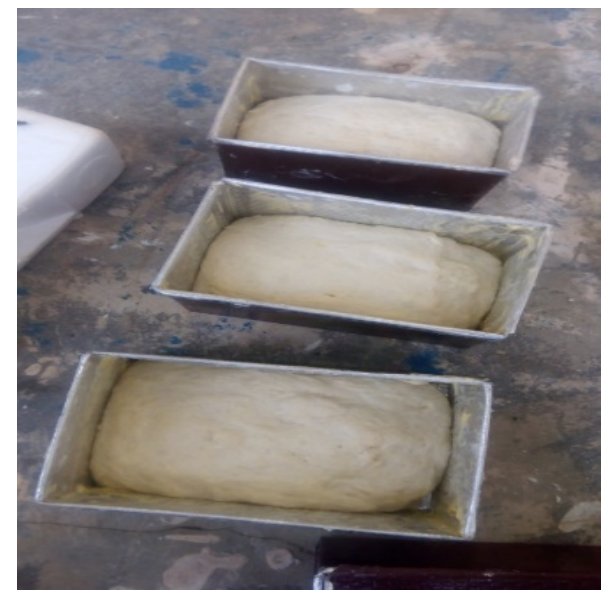

Plate 2. The bread dough preparation.

Baking capacity: the number of pieces of the bread dough in each baking compartment depends on the arrangement of the food samples in the baking chamber. The baking capacity of the oven was determined by putting into consideration the size of the baking pan and the dough weight.

Baking Efficiency: the baking efficiency of the oven is calculated as the output energy per input energy of the baking oven. This is expressed in percentage and can be expressed mathematically [8] as;

$$
\text { Baking Efficiency }=\frac{\text { Output energy }}{\text { Input energy }} \times \frac{100}{1}
$$

Weight loss in the food samples: this is the weight losses encountered during the operation of oven. The weight loss in the food samples (bread dough) was calculated by subtracting the weight of the food sample after heating from the initial weight of the food sample. The percentage of moisture loss was obtained using Equation (2).

$$
\begin{aligned}
\text { Weight loss } & =\text { Initial Weight }- \text { Final Weight } \% \text { Moisture Loss } \\
& =\frac{\text { Initial Weight }- \text { Final Weight }}{\text { Initial weight }} \times \frac{100}{1}
\end{aligned}
$$

Oven spring: the sudden rise or rapidly expansion of dough during the first ten (10) minutes in the oven is called oven-spring. Several factors may influence oven-spring. The quantum of heat energy and increase in volume of dough, moisture content and carbon dioxide. All this causes increase in internal pressure of dough and the dough rise rapidly in the initial stage of baking. The yeast activity decreases as the dough warms and the yeast is inactivated at $55^{\circ} \mathrm{C}$ [13]. This oven-spring of the bread dough was measured in terms of vertical height using a digital vertical-height venial caliper (0 - $300 \mathrm{~mm}$, Mutitoyus Germany).

Physical properties of the food sample: for the effective investigation of the oven-spring of the baked bread, these other physical properties were evaluated in terms of surface area, specific volume, density and relative density. Each property was determined using the mathematical Equations (3) - (6) [14]. 


$$
\begin{gathered}
\text { Surface Area, } S A=2(l b+b h+l h) \\
\text { Volume, } V=\text { Length } \times \text { Breadth } \times \text { Height } \\
\text { Density, } \rho=\frac{\text { Mass }}{\text { Volume }} \\
\text { Specific Volume, } S V=\frac{\text { Volume }}{\text { Mass }}
\end{gathered}
$$

\section{Results and Discussion}

The modified baking oven is shown in Plate 2. It was observed that the rate of oven-spring was higher at $150^{\circ} \mathrm{C}$ baking temperature than other baking temperatures and that browning reaction increase as baking temperature increases. It was established further that visible browning reaction was more pronounced at baking temperature of $150^{\circ} \mathrm{C}$. This browning reaction is chiefly responsible for the development of the attractive bread flavor and typical browning coloration of the bread crust which enhances the firmness. These observations were in agreement with the reports of [9] [13] and [15].

\section{Baking capacity}

The baking oven has six baking partitions in each compartment, a total of 96 pieces of bread dough in baking pans of size $153 \mathrm{~mm} \times 103 \mathrm{~mm} \times 76 \mathrm{~mm}$ was attained. The baking chamber of the baking oven has a volume of $0.41 \mathrm{~m}^{3}$. It can bake 144 pieces of bread dough in one batch. Therefore, the baking oven has maximum baking capacity of $101.9 \mathrm{~kg} / \mathrm{hr}$.

\section{The baking efficiency}

Table 1 show the baking efficiency for wood-fired and gas-fired at the three selected temperature levels. It was observed that baking efficiencies increased as

Table 1. Baking efficiency for wood-fired and gas-fired at the three temperatures.

\begin{tabular}{cccc}
\hline & \multicolumn{3}{c}{ Baking Temperature $\left({ }^{\circ} \mathrm{C}\right)$} \\
\hline Weight of Dough (g) & 140 & 145 & 150 \\
\hline Wood-fired & & & \\
100 & 46.25 & 43.32 & 43.30 \\
150 & 44.96 & 42.12 & 42.09 \\
200 & 51.39 & 48.14 & 48.11 \\
250 & 51.39 & 48.14 & 48.11 \\
Average Baking Efficiency (\%) & 48.4975 & 45.43 & 45.4025 \\
Gas-fired & & & \\
100 & 84.56 & 66.93 & 50.25 \\
150 & 82.21 & 65.07 & 48.85 \\
200 & 93.95 & 74.36 & 55.00 \\
250 & 93.95 & 74.36 & 55.00 \\
Average Baking Efficiency (\%) & 88.6675 & 70.18 & 52.275 \\
\hline
\end{tabular}


the baking temperature increases. The optimum baking efficiency of the oven occurred at the $150^{\circ} \mathrm{C}$ baking temperature. Most especially when the weight of dough was increased to $250 \mathrm{~g}$. This may be due to the increased in the surface area of the bread dough to absorb maximum thermal energy dissipated from the heat exchangers. The baking efficiency of the firewood and liquefied petroleum gas estimated as $45.43 \%$ and $52.28 \%$, respectively.

\section{The weight loss}

The results of the weight loss during the baking process of the bread dough at different baking temperatures $\left(140^{\circ} \mathrm{C}, 145^{\circ} \mathrm{C}\right.$ and $\left.150^{\circ} \mathrm{C}\right)$ as shown in Figure 1 , the baking temperature increases linearly as the weight loss increased. Furthermore, it can be observed that the weight loss increased with increased in time. More importantly, it was also observed that at the increased of baking temperature from $140^{\circ} \mathrm{C}-150^{\circ} \mathrm{C}$, there was a corresponding increase in weight loss from

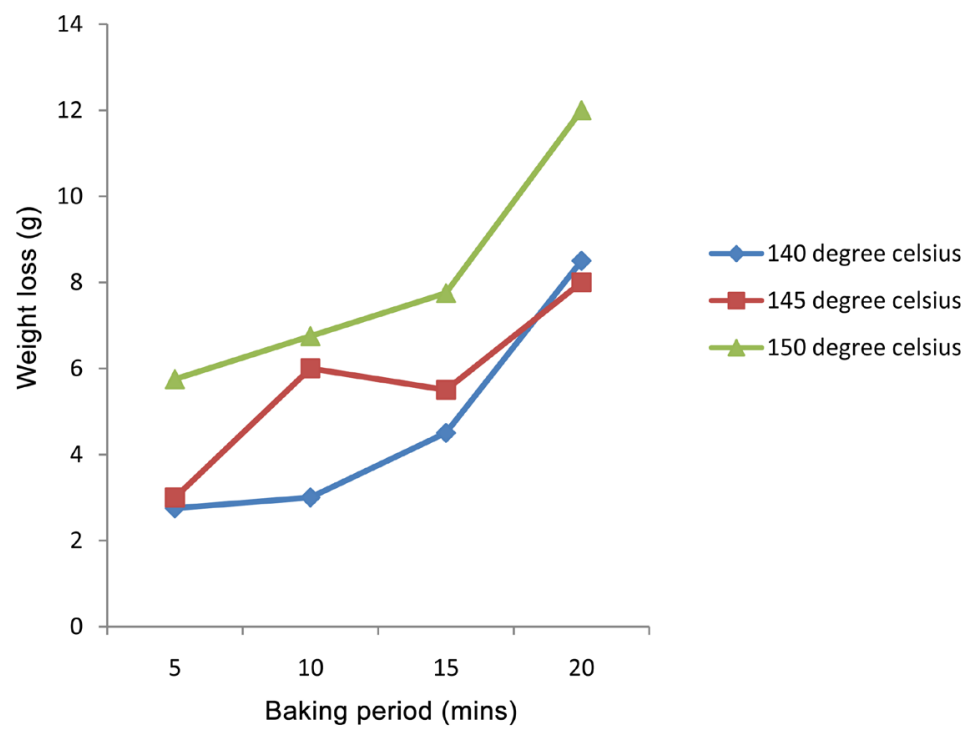

(a)

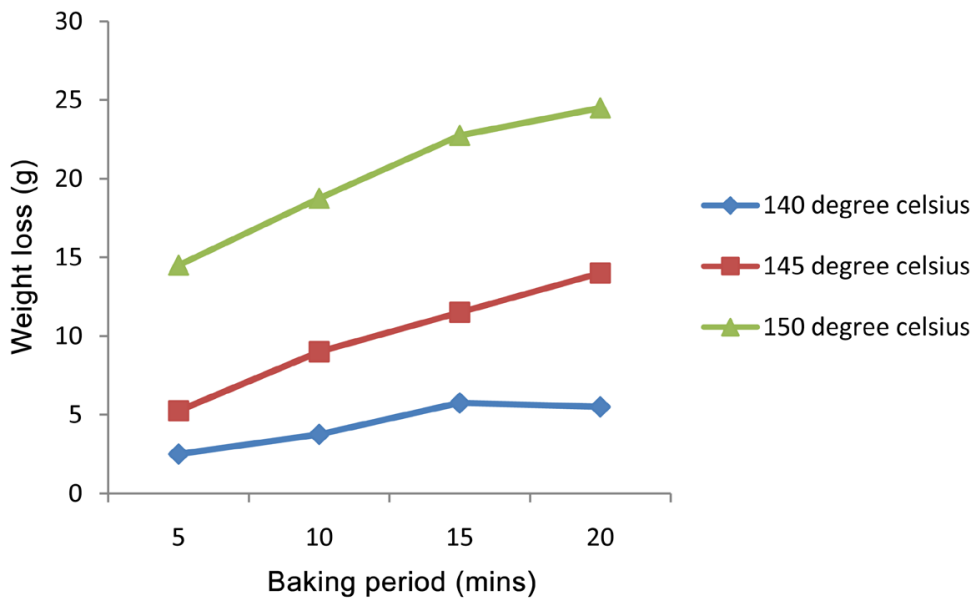

(b)

Figure 1. Weight loss of dough at various level of baking period. 
7.9 to $12.5 \mathrm{~g}$. Likewise the maximum weight loss at the baking temperature of $140^{\circ} \mathrm{C}$ was $7.9 \mathrm{~g}$, while that of $150^{\circ} \mathrm{C}$ was $12.5 \mathrm{~g}$. There was no much disparity between the weight loss in dough during the baking at $140^{\circ} \mathrm{C}$ and $145^{\circ} \mathrm{C}$. However, there was a tremendous weight loss at the baking temperature of $150^{\circ} \mathrm{C}$ comparatively. Hence as the baking time increased moisture loss increased, which resulted to reduction in the final weight of the baked dough. The same observation was reported by [9] and [10] on moisture loss and modelling heat transfer at the evaluation of the gas-fired bread baking ovens. These results were also synonymous to previous research report of [16] on moisture loss during baking of bread dough using gas-fired oven.

\section{Physical properties of baked bread wood-fired and gas-fired}

Effect of baking temperature and weight of dough on the surface area SA of the baked bread

There was strong and significant influence of the quadratic factors of baking temperature $T$ and weight of dough $W$ on the surface area of baked bread. Statistical analysis conducted on the data showed that baking temperature and weight of dough had significant $(p<0.05)$ quadratic effects on the regression models for both wood-fired and gas-fired (Table 2 and Table 3 ). The models could explain $92 \%$ and $97 \%$ of the variation in surface area of baked bread for both wood-fired and gas-fired oven respectively (Equations (7) and (8)), meaning only $8 \%$ and $3 \%$ of the variations were due to other factors not included in the models. The response plots (Figure 2(a) and Figure 2(b)) show that baking temperature and weight of dough had significant effect on the surface area of the baked bread with significant interaction between the factors. The response surface plots generated showed curvilinear plots with both the baking temperature and the weight of dough. This implies that the surface area of baked bread increased as weight of dough and baking temperature increased.

Table 2. Physical properties of baked dough for 20 mins.

\begin{tabular}{cccccccccc}
\hline \multirow{2}{*}{$\begin{array}{c}\text { Baking } \\
\text { temperature }\end{array}$} & Weight of & \multicolumn{2}{c}{ Surface Area $\left(\mathrm{cm}^{2}\right)$} & \multicolumn{2}{c}{ Volume $\left(\mathrm{cm}^{3}\right)$} & \multicolumn{2}{c}{ Density $\left(\mathrm{g} / \mathrm{cm}^{3}\right)$} & \multicolumn{2}{c}{ Specific Volume $\left(\mathrm{cm}^{3} / \mathrm{g}\right)$} \\
\cline { 2 - 10 } & Dough $(\mathrm{g})$ & Firewood & Gas & Firewood & Gas & Firewood & Gas & Firewood & Gas \\
\hline \multirow{3}{*}{$140^{\circ} \mathrm{C}$} & 100 & $342 \mathrm{~d} \pm 5.84$ & $305 \mathrm{~d} \pm 9.35$ & $375 \mathrm{~d} \pm 11.29$ & $339 \mathrm{~d} \pm 16.81$ & $0.28 \pm 0.00$ & $0.30 \pm 0.02$ & $3.75 \pm 0.11$ & $3.40 \pm 0.17$ \\
& 150 & $414 \mathrm{c} \pm 4.94$ & $416 \mathrm{c} \pm 7.80$ & $543 \mathrm{c} \pm 11.15$ & $550 \mathrm{c} \pm 17.54$ & $0.28 \pm 0.00$ & $0.27 \pm 0.01$ & $3.62 \pm 0.07$ & $3.67 \pm 0.12$ \\
& 200 & $507 \mathrm{~b} \pm 4.9$ & $506 \mathrm{~b} \pm 5.69$ & $729 \mathrm{~b} \pm 11.22$ & $722 \mathrm{~b} \pm 14.49$ & $0.28 \pm 0.00$ & $0.28 \pm 0.00$ & $3.65 \pm 0.06$ & $3.61 \pm 0.07$ \\
& 250 & $582 \mathrm{a} \pm 5.66$ & $605 \mathrm{a} \pm 1.08$ & $876 \mathrm{a} \pm 14.85$ & $929 \mathrm{a} \pm 2.43$ & $0.28 \pm 0.00$ & $0.27 \pm 0.00$ & $3.51 \pm 0.06$ & $3.72 \pm 0.01$ \\
\hline \multirow{3}{*}{$145^{\circ} \mathrm{C}$} & 100 & $321 \mathrm{~d} \pm 6.74$ & $304 \mathrm{~d} \pm 12.14$ & $364 \mathrm{~d} \pm 14.04$ & $336 \mathrm{~d} \pm 22.98$ & $0.28 \pm 0.01$ & $0.30 \pm 0.02$ & $3.64 \pm 0.14$ & $3.36 \pm 0.23$ \\
& 150 & $392 \mathrm{c} \pm 8.46$ & $407 \mathrm{c} \pm 13.85$ & $494 \mathrm{c} \pm 18.46$ & $527 \mathrm{c} \pm 31.14$ & $0.28 \pm 0.01$ & $0.29 \pm 0.02$ & $3.30 \pm 0.12$ & $3.52 \mathrm{bc} \pm 0.21$ \\
& 200 & $506 \mathrm{ab} \pm 23.98$ & $506 \mathrm{~b} \pm 7.49$ & $727 \mathrm{ab} \pm 61.77$ & $730 \mathrm{~b} \pm 19.38$ & $0.30 \pm 0.02$ & $0.28 \mathrm{c} \pm 0.01$ & $3.63 \pm 0.31$ & $3.65 \mathrm{bc} \pm 0.10$ \\
& 250 & $548 \mathrm{ab} \pm 10.98$ & $579 \mathrm{a} \pm 9.17$ & $791 \mathrm{ab} \pm 23.05$ & $867 \mathrm{a} \pm 24.48$ & $0.30 \pm 0.01$ & $0.29 \pm 0.01$ & $3.16 \pm 0.09$ & $3.47 \pm 0.10$ \\
\hline \multirow{3}{*}{$150^{\circ} \mathrm{C}$} & 100 & $345 \mathrm{~d} \pm 7.37$ & $346 \mathrm{~d} \pm 11.55$ & $417 \mathrm{~d} \pm 14.41$ & $417 \mathrm{~d} \pm 30.22$ & $0.24 \pm 0.01$ & $0.25 \mathrm{~d} \pm 0.02$ & $4.17 \mathrm{a} \pm 0.14$ & $3.33 \mathrm{~d} \pm 0.30$ \\
& 150 & $431 \mathrm{c} \pm 8.16$ & $427 \mathrm{c} \pm 7.13$ & $583 \mathrm{c} \pm 17.44$ & $570 \mathrm{c} \pm 16.94$ & $0.26 \pm 0.01$ & $0.27 \mathrm{bc} \pm 0.01$ & $3.90 \mathrm{bc} \pm 0.11$ & $3.69 \mathrm{bc} \pm 0.11$ \\
& 200 & $512 \mathrm{~b} \pm 4.80$ & $510 \mathrm{~b} \pm 7.84$ & $743 \mathrm{~b} \pm 14.63$ & $737 \mathrm{~b} \pm 20.25$ & $0.27 \pm 0.00$ & $0.27 \mathrm{bc} \pm 0.01$ & $3.72 \mathrm{~d} \pm 0.73$ & $3.80 \mathrm{bc} \pm 0.10$ \\
& 250 & $604 \mathrm{a} \pm 15.66$ & $566 \mathrm{a} \pm 6.65$ & $943 \mathrm{a} \pm 4.04$ & $833 \mathrm{a} \pm 21.86$ & $0.27 \pm 0.01$ & $0.30 \mathrm{a} \pm 0.01$ & $3.77 \mathrm{bc} \pm 0.16$ & $4.17 \mathrm{a} \pm 0.09$ \\
\hline
\end{tabular}

Means are significantly different at $p<0.05$. 


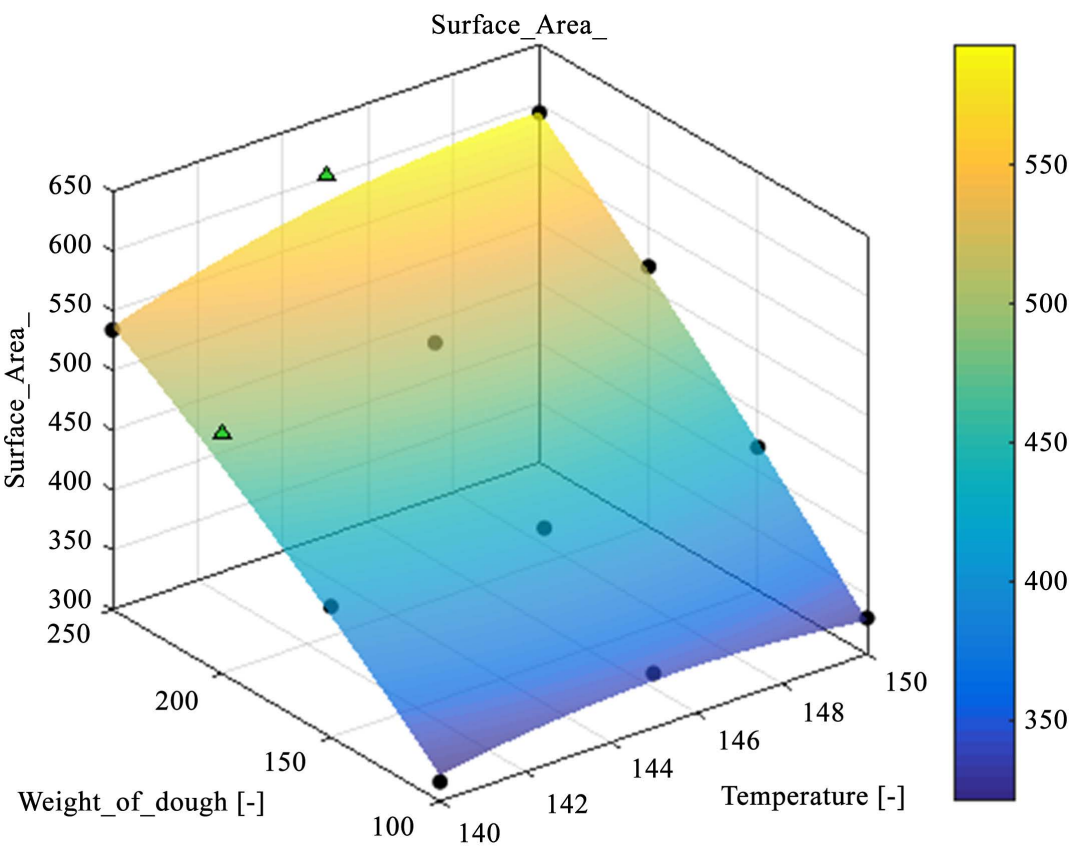

(a)

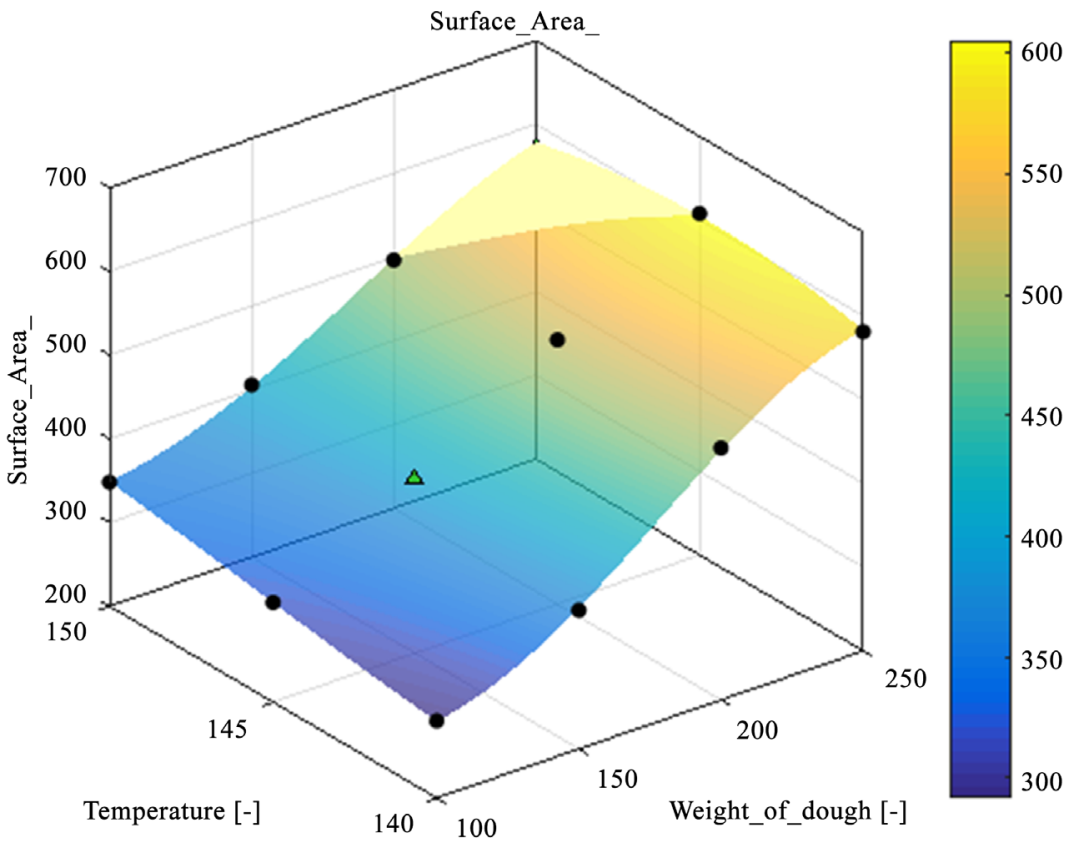

(b)

Figure 2. Surface plot for determining the optimum surface area of the baked bread at varying baking temperature and weight of dough ((a) wood-fired and (b) gas-fired).

$$
\begin{aligned}
S A= & 468.7066+15.85283 T+120.2975 W-14.32884 T^{2} \\
& +12.5867 T W-9.160002 W^{2} \text { with an } R^{2} \text { of } 0.92 \\
S A= & 465.9127+12.15145 T+134.1618 W-18.79129 T^{2} \\
& -19.19787 T W \text { with an } R^{2} \text { of } 0.97
\end{aligned}
$$


Table 3. One-way ANOVA of physical properties of baked dough for $20 \mathrm{~min}$.

\begin{tabular}{|c|c|c|c|c|c|c|c|}
\hline Temperature & $\begin{array}{r}\text { Physic } \\
\text { of Ba }\end{array}$ & $\begin{array}{l}\text { al Properties } \\
\text { ked Dough }\end{array}$ & $\begin{array}{l}\text { Sum of } \\
\text { Squares }\end{array}$ & Df & Mean Square & $\mathrm{F}$ & Sig \\
\hline \multirow{4}{*}{$140^{\circ} \mathrm{C}$} & $\begin{array}{c}\text { Surface } \\
\text { Area }\left(\mathrm{cm}^{2}\right)\end{array}$ & $\begin{array}{c}\text { Between Groups } \\
\text { Within Group } \\
\text { Total }\end{array}$ & $\begin{array}{c}48.11805 \\
79,558.3591 \\
79,606.47715\end{array}$ & $\begin{array}{l}1 \\
6 \\
7\end{array}$ & $\begin{array}{c}48.11805 \\
13,259.72652\end{array}$ & 5.987377607 & 0.00 \\
\hline & $\begin{array}{l}\text { Volume } \\
\left(\mathrm{cm}^{3}\right)\end{array}$ & $\begin{array}{c}\text { Between Groups } \\
\text { Within Group } \\
\text { Total }\end{array}$ & $\begin{array}{c}101.9592 \\
301,161.4626 \\
301,263.4218\end{array}$ & $\begin{array}{l}1 \\
6 \\
7\end{array}$ & $\begin{array}{c}101.9592 \\
50,193.57709\end{array}$ & 5.987377607 & 0.00 \\
\hline & $\begin{array}{l}\text { Density } \\
\left(\mathrm{g} / \mathrm{cm}^{3}\right)\end{array}$ & $\begin{array}{c}\text { Between Groups } \\
\text { Within Group } \\
\text { Total }\end{array}$ & $\begin{array}{c}0.0021125 \\
0.003475 \\
0.0055875\end{array}$ & $\begin{array}{l}1 \\
6 \\
7\end{array}$ & $\begin{array}{c}0.0021125 \\
0.000579167\end{array}$ & 5.987377607 & 3.64 \\
\hline & $\begin{array}{l}\text { Specific } \\
\text { Volume } \\
\left(\mathrm{cm}^{3} / \mathrm{g}\right)\end{array}$ & $\begin{array}{c}\text { Between Groups } \\
\text { Within Group } \\
\text { Total }\end{array}$ & $\begin{array}{c}0.0435125 \\
0.464675 \\
0.5081875\end{array}$ & $\begin{array}{l}1 \\
6 \\
7\end{array}$ & $\begin{array}{c}0.0435125 \\
0.077445833\end{array}$ & 5.987377607 & 0.56 \\
\hline \multirow{4}{*}{$145^{\circ} \mathrm{C}$} & $\begin{array}{c}\text { Surface } \\
\text { Area } \\
\left(\mathrm{cm}^{2}\right)\end{array}$ & $\begin{array}{c}\text { Between Groups } \\
\text { Within Group } \\
\text { Total }\end{array}$ & $\begin{array}{c}82.30445 \\
85,643.3779 \\
85,725.68235\end{array}$ & $\begin{array}{l}1 \\
6 \\
7\end{array}$ & $\begin{array}{c}82.30445 \\
14,273.89632\end{array}$ & 5.987377607 & 0.00 \\
\hline & $\begin{array}{l}\text { Volume } \\
\left(\mathrm{cm}^{3}\right)\end{array}$ & $\begin{array}{c}\text { Between Groups } \\
\text { Within Group } \\
\text { Total }\end{array}$ & $\begin{array}{c}649.2606125 \\
343,669.6699 \\
344,318.9305\end{array}$ & $\begin{array}{l}1 \\
6 \\
7\end{array}$ & $\begin{array}{l}649.2606125 \\
57278.27831\end{array}$ & 5.987377607 & 0.01 \\
\hline & $\begin{array}{l}\text { Density } \\
\left(\mathrm{g} / \mathrm{cm}^{3}\right)\end{array}$ & $\begin{array}{c}\text { Between Groups } \\
\text { Within Group } \\
\text { Total }\end{array}$ & $\begin{array}{c}0.0002 \\
0.001 \\
0.0012\end{array}$ & $\begin{array}{l}1 \\
6 \\
7\end{array}$ & $\begin{array}{c}0.0002 \\
0.000166667\end{array}$ & 5.987377607 & 1.20 \\
\hline & $\begin{array}{l}\text { Specific } \\
\text { Volume } \\
\left(\mathrm{cm}^{3} / \mathrm{g}\right)\end{array}$ & $\begin{array}{c}\text { Between Groups } \\
\text { Within Group } \\
\text { Total }\end{array}$ & $\begin{array}{c}0.05445 \\
0.1951 \\
0.24955\end{array}$ & $\begin{array}{l}1 \\
6 \\
7\end{array}$ & $\begin{array}{c}0.05445 \\
0.032516667\end{array}$ & 5.987377607 & 1.67 \\
\hline \multirow{4}{*}{$150^{\circ} \mathrm{C}$} & $\begin{array}{c}\text { Surface } \\
\text { Area } \\
\left(\mathrm{cm}^{2}\right)\end{array}$ & $\begin{array}{c}\text { Between Groups } \\
\text { Within Group } \\
\text { Total }\end{array}$ & $\begin{array}{c}179.7408 \\
68,425.299 \\
68,605.0398\end{array}$ & $\begin{array}{l}1 \\
6 \\
7\end{array}$ & $\begin{array}{c}179.7408 \\
11,404.2165\end{array}$ & 5.987377607 & 0.02 \\
\hline & $\begin{array}{l}\text { Volume } \\
\left(\mathrm{cm}^{3}\right)\end{array}$ & $\begin{array}{c}\text { Between Groups } \\
\text { Within Group } \\
\text { Total }\end{array}$ & $\begin{array}{l}2060.499013 \\
262,427.3632 \\
264,487.8622\end{array}$ & $\begin{array}{l}1 \\
6 \\
7\end{array}$ & $\begin{array}{c}2060.499013 \\
43,737.89386\end{array}$ & 5.987377607 & 0.05 \\
\hline & $\begin{array}{l}\text { Density } \\
\left(\mathrm{g} / \mathrm{cm}^{3}\right)\end{array}$ & $\begin{array}{c}\text { Between Groups } \\
\text { Within Group } \\
\text { Total }\end{array}$ & $\begin{array}{c}0.0003125 \\
0.002475 \\
0.0027875\end{array}$ & $\begin{array}{l}1 \\
6 \\
7\end{array}$ & $\begin{array}{l}0.0003125 \\
0.0004125\end{array}$ & 5.987377607 & 0.76 \\
\hline & $\begin{array}{l}\text { Specific } \\
\text { Volume } \\
\left(\mathrm{cm}^{3} / \mathrm{g}\right)\end{array}$ & $\begin{array}{c}\text { Between Groups } \\
\text { Within Group } \\
\text { Total }\end{array}$ & $\begin{array}{c}0.0253125 \\
0.489075 \\
0.5143875\end{array}$ & $\begin{array}{l}1 \\
6 \\
7\end{array}$ & $\begin{array}{l}0.0253125 \\
0.0815125\end{array}$ & 5.987377607 & 0.31 \\
\hline
\end{tabular}

\section{Effect of baking temperature and weight of dough on the volume $V$ of the} baked bread

The results of regression analysis show that both the baking temperature $T$ and the weight of dough $W$ did affect the volume of the baked bread $(p<0.05)$ for both wood-fired and gas-fired (Table 2 and Table 3 ). The analysis of variance reveals that regression was statistically significant at $84 \%$ and $92 \%$ confidence level, Equations (9) and (10) for both wood-fired and gas-fired oven respectively and high coefficient of determinations $\left(R^{2}=0.84\right.$ and 0.92$)$ demonstrates that the model could be used to explain $84 \%$ and $92 \%$ of the total variation in the response for both wood-fired and gas-fired oven respectively. Figure 
3(a) and Figure 3(b) shows that volume of baked bread optimization required simultaneous increase in weight of dough and baking temperature. The best volumes were attained working at high weight of dough and high temperature, conditions under which a slight increase in the parameters will yield a corresponding increase in the volume of baked bread.

$$
\begin{aligned}
V=660.7713+38.11508 T+255.3114 W-34.15368 T^{2} \\
+35.86665 T W \text { with an } R^{2} \text { of } 0.84 \\
V=593.7897+283.7631 W-67.9982 T W \\
\quad+51.31656 W^{2} \text { with an } R^{2} \text { of } 0.92
\end{aligned}
$$

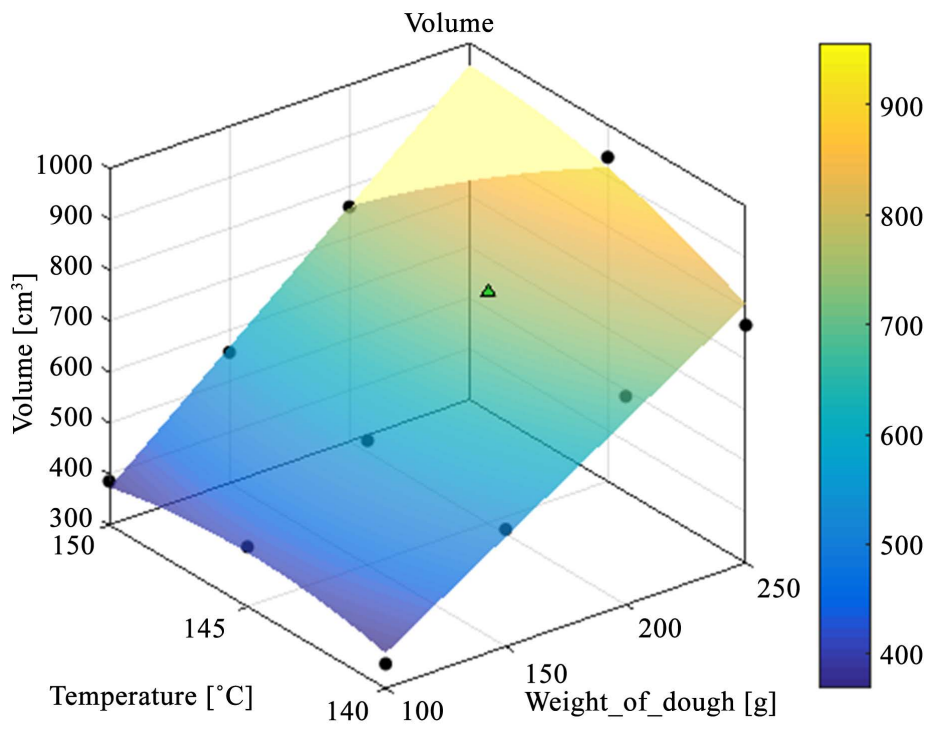

(a)

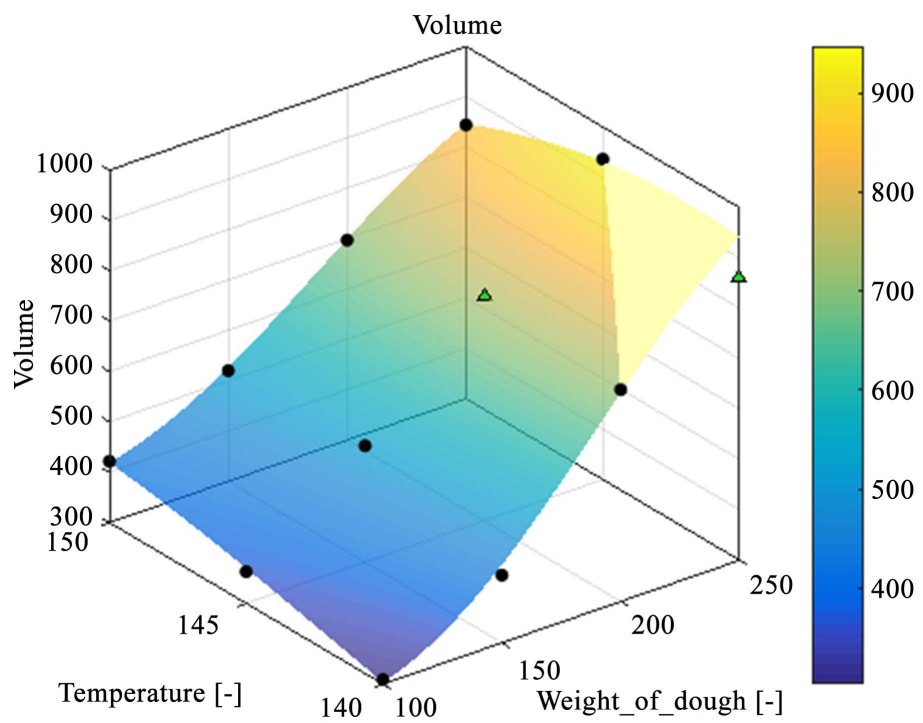

(b)

Figure 3. Surface plot for determining the optimum volume of the baked bread at varying baking temperature and weight of dough ((a) wood-fired and (b) gas-fired). 


\section{Effect of baking temperature and weight of dough on the density $\rho$ of the} baked bread

There was non-significant ( $p=3.64,1.200$ and 0.758$)$ influence of the quadratic factors of weight of dough $W$ and baking temperature $T$ on density. It was observed from the statistical analysis that both the weight of dough and baking temperature showed a non-significant $(p>0.05)$ quadratic effect on the model for both wood-fired and gas-fired oven (Table 2 and Table 3), Equations (11) and (12), respectively. The model could explain about $82 \%$ and $88 \%$ of the variations in density for both wood-fired and gas-fired oven respectively. Figure 4(a) and Figure 4(b) show the response plots of the effect of both the baking temperature and the weight of dough on the density for both wood-fired and gas-fired oven. The predicted model and the response surface confirmed that the baking temperature and weight of dough have a negligible effect on density of baked bread.

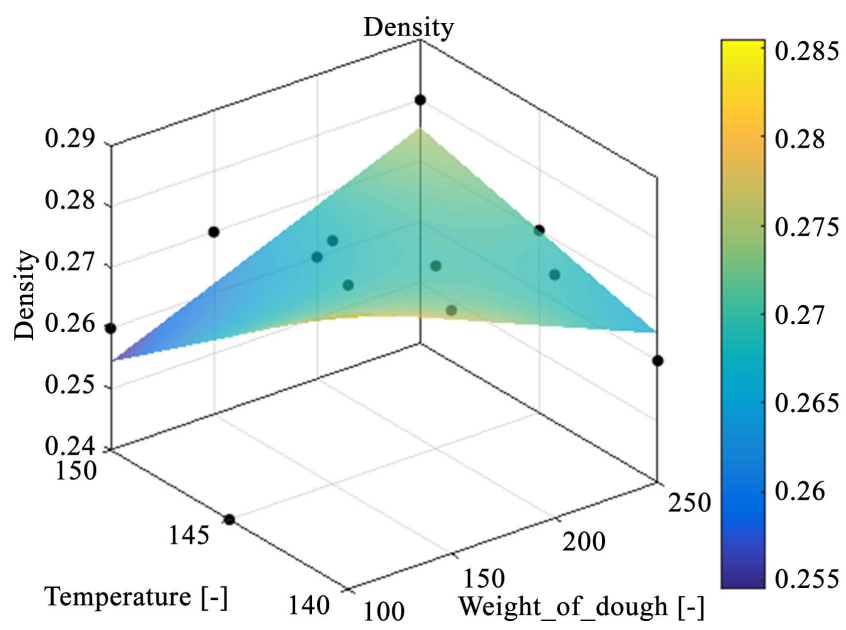

(a)

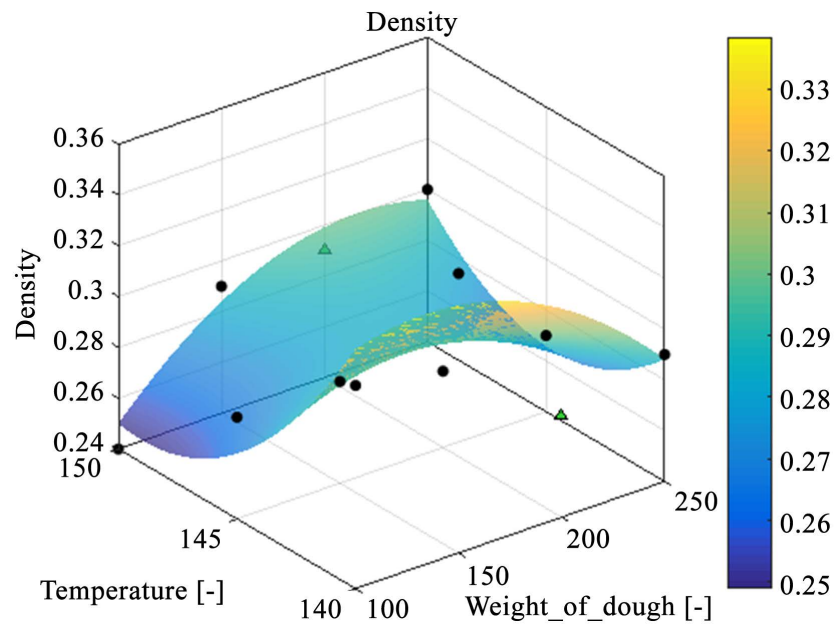

(b)

Figure 4. Surface plot for determining the optimum density of the baked bread at varying baking temperature and weight of dough ((a) wood-fired and (b) gas-fired). 


$$
\begin{aligned}
\rho= & 0.26984-0.015435 T+0.011609 W+0.024913 T W \\
& -0.012228 W^{2} \text { with an } R^{2} \text { of } 0.82 \\
\rho= & 0.28661-0.019107 T+0.026429 T^{2}+0.023036 T W \\
& -0.020893 W^{2} \text { with an } R^{2} \text { of } 0.88
\end{aligned}
$$

Effect of baking temperature and weight of dough on the specific volume $S V$ of the baked bread

The results of regression analysis show that baking temperature $T$ and weight of dough $W$ did not affect specific volume of baked bread ( $p>0.05)$, the analysis of variance reveals that regression was statistically not significant at $96 \%$ and 85\% confidence level (Table 2 and Table 3), Equations (13) and (14) for both wood-fired and gas-fired oven respectively. The coefficient of determination $\left(R^{2}\right.$ $=0.96$ and 0.85 ) demonstrates that the model could explain $96 \%$ and $85 \%$ of the total variation in the response for both wood-fired and gas-fired oven respectively. Figure 5(a) and Figure 5(b) show specific volume optimization not affected by change in the baking temperature and weight of dough.

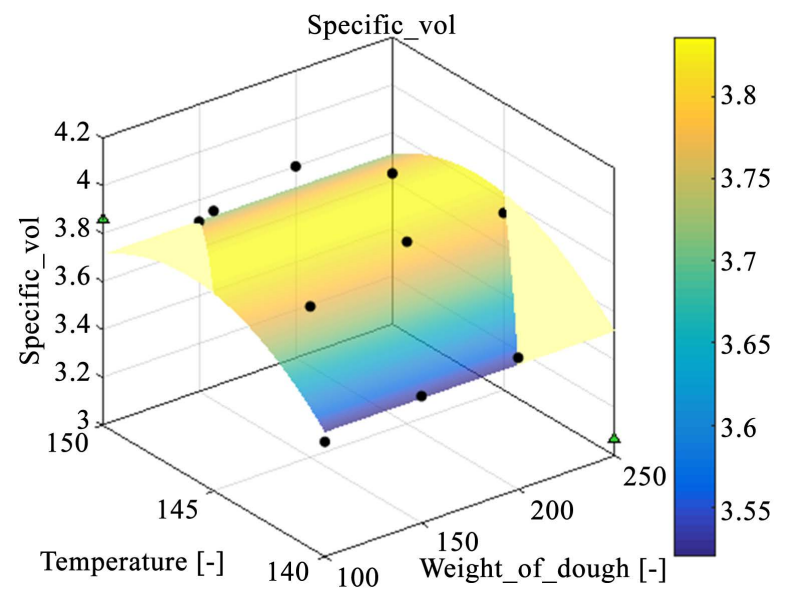

(a)

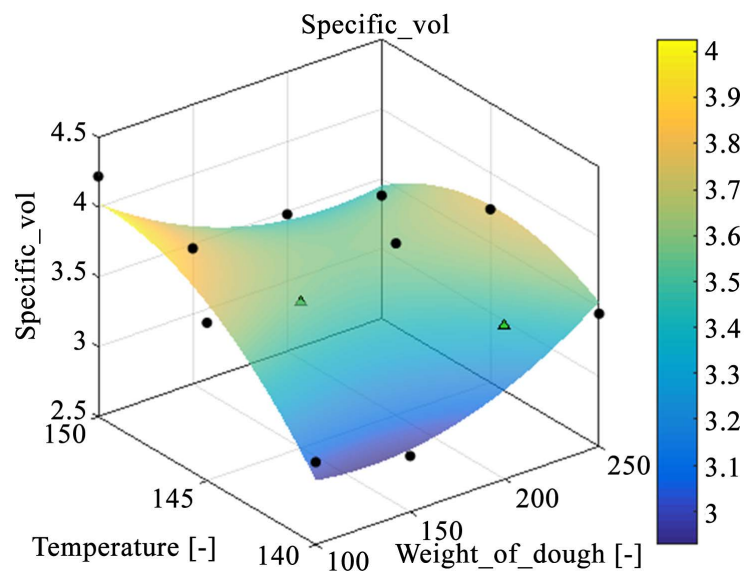

(b)

Figure 5. Surface plot for determining the optimum specific volume of the baked bread at varying baking temperature and weight of dough ((a) wood-fired and (b) gas-fired). 


$$
\begin{gathered}
S V=3.5379+0.24653 T-0.2749 T^{2}-0.28708 T W \\
+0.2304 W^{2} \text { with an } R^{2} \text { of } 0.85 \\
S V=3.7958+0.1875 T-0.1725 W-0.20083 T^{2} \text { with an } R^{2} \text { of } 0.96
\end{gathered}
$$

\section{Conclusion}

The existing baking oven was modified to a dual powered baking oven and evaluated by considering the baking oven characteristics as baking capacity, baking efficiency, weight loss and optimum baking temperature and physical properties. The average baking efficiency of wood-fired and gas-fired were $46.44 \%$ and $70.34 \%$, respectively, indicating that, energy was efficiently used in gas-fired than wood-fired. The surface area and volume of baked bread wood-fired oven compared with gas-fired oven were significantly different from each other at level of $(p<0.05)$, whereas the effect of the factors were not significant for the density and specific volume, with optimum baking temperature between $145^{\circ} \mathrm{C}-150^{\circ} \mathrm{C}$. Therefore, the modified oven can be used for the baking of dough at domestic, small and medium scale bakery.

\section{Conflicts of Interest}

The authors declare no conflicts of interest regarding the publication of this paper.

\section{References}

[1] Tong, C.H. and Lund, D.B. (1990) Effective Moisture Diffusivity in Porous Materials as a Function of Temperature and Moisture Content. Biotechnology Progress, 6, 67-75. https://doi.org/10.1021/bp00001a011

[2] Mondal, A. and Data, A.K. (2008) Bread baking-A Review. Journal of Food Engineering, 86, 465-474. https://doi.org/10.1016/j.jfoodeng.2007.11.014

[3] Ozilgen, M. and Heil, J.R. (1994). Mathematical Modeling of Transient Heat and Mass Transport in a Baking Process. Journal of Food Processing and Preservation, 18, 133-148. https://doi.org/10.1111/j.1745-4549.1994.tb00248.x

[4] Basil, E. and Blessent, J. (2014) Development and Application of a Uniform Testing Procedure for Ovens, Pacific Gas and Electric Company. Department of Research and Development Report, 4, 10-25.

[5] Ogunjobi, M.A. and Ogunwole, S.O. (2010) Physiochemical and Sensory Properties of Cassava Flour Biscuits Supplemented with Cashew Apple Powder. Journal of Food Technology, 8, 24-29. https://doi.org/10.3923/jftech.2010.24.29

[6] Adebowale, A., Adegoke, M., Sanni, S., Adegunwa, M. and Fatuga, G. (2012) Functional Properties and Biscuit Making Potentials of Sorghum-Wheat Flour Composite. America Journal Technology, 7, 372-379. https://doi.org/10.3923/ajft.2012.372.379

[7] Aborisade, D.O. and Adewuyi, P.A. (2014) Evaluation of PID Tuning Method on Direct Gas Fired Oven. International Journal of Engineering Research and Application, 4, 01-09.

[8] Okafor-Basil, E. (2014) Simple Design of a Dual-Powered Domestic Oven. Interna- 
tional Journal of Engineering and Technology, 4, 1-13.

[9] Genitha, I., Lakshmana-Gowda, B.T. and Raj, D.J. (2014) Design, Fabrication of Domestic Gas Oven. IOSR Journal of Engineering, 4, 35-38.

https://doi.org/10.9790/3021-04553538

[10] Carvalho, M. and Martins, N. (1993) Mathematical Modelling of Heat and Mass Transfer in a Forced Convection Baking Oven. AICHE Symposium Series-Heat Transfer, 88, 205-211.

[11] Fellows, P.J. (2000) Food Processing Technology-Principles and Practice. Wood head Publishing Limited, Cambridge. https://doi.org/10.1201/NOE0849308871

[12] Therdthai, N., Zhou, W. and Thomas, A. (2003) Three-Dimensional CFD Modelling and Simulation of the Temperature Profiles and Air Flow Patterns during a Continuous Industrial Baking Process. Journal of Food Engineering, 65, 599-608. https://doi.org/10.1016/j.jfoodeng.2004.02.026

[13] Khatkar, B.S. (2004). Bread Industry and Processes. Thesis of Post Graduate Diploma in Bakery Science and Technology. Directorate of Distance Education Guru Jambheshwar, University of Science and Technology, 1-86.

[14] Avadhanula, M. (2002) Engineering Physics (3rd, Ed) S. Chand, 5, 700-705.

[15] Hoffman, T. and Lindenmeier, M. (2004) Influence of Baking Conditions and Precursors Supplementation on the Amounts of the Antioxidant Pronyl-1-Lysine in Bakery Products. Journal of Agricultural and Food Chemistry, 52, 350-354. https://doi.org/10.1021/jf0346657

[16] Bahnasawy, A.H. and Khater, E.G. (2014) Heat and Mass Balance for Baking Process. Journal of Bioprocess Biotech, 4, 3-6. 